\title{
In vitro evaluation of the effect of botanical formulations used in the control of Aedes aegypti L. (Diptera: Culicidae) on liver enzymes.
}

\author{
Karla Rejane de Andrade Porto ${ }^{[1]}$, Priscilla Rezende Motti ${ }^{[2]}$, \\ Alexandre Alves Machado ${ }^{[3]}$ and Antonia Railda Roe[ ${ }^{[1],[2],[3]}$
}

\begin{abstract}
[1]. Programa de Pós-Graduação em Biotecnologia e Biodivesidade - Rede Pro Centro-Oeste, Universidade Federal de Mato Grosso do Sul, Campo Grande, Mato Grosso do Sul, Brasil. [2]. Programa de Pós-Graduação em Biotecnologia, Universidade Católica Dom Bosco, Campo Grande, Mato Grosso do Sul, Brasil. [3]. Departamento de Pesquisa, Universidade Católica Dom Bosco, Campo Grande, Mato Grosso do Sul, Brasil.
\end{abstract}

\begin{abstract}
Introduction: Dengue fever is a viral disease transmitted by the Aedes aegypti Linn. (1792) (Diptera: Culicidae) mosquito, which is endemic in several regions of Brazil. Alternative methods for the control of the vector include botanical insecticides, which offer advantages such as lower environmental contamination levels and less likelihood of resistant populations. Thus, in this study, the ability of botanical insecticide formulations to inhibit the activity of the liver enzymes serum cholinesterase and malate dehydrogenase was evaluated. Methods: Inhibition profiles were assessed using in vitro assays for cholinesterase and malate dehydrogenase activity and quantitated by ultraviolet-visible spectroscopy at $410 \mathrm{~nm}$ to $340 \mathrm{~nm}$. Results: Insecticide products formulated from cashew nutshell liquid [A] and ricinoleic acid [B] showed cholinesterase activity levels of $6.26 \mathrm{IU} / \mathrm{mL}$ and $6.61 \mathrm{IU} / \mathrm{mL}$, respectively, while the control level for cholinesterase was $5-12 \mathrm{IU} / \mathrm{mL}$. The products did not affect the level of $0.44 \mathrm{IU} / \mathrm{mL}$ established for malate dehydrogenase, as the levels produced by $[\mathrm{A}]$ and $[\mathrm{B}]$ were $0.43 \mathrm{IU} / \mathrm{mL}$ and $0.45 \mathrm{IU} / \mathrm{mL}$, respectively. Conclusions: Our findings show that in vitro testing of the formulated products at concentrations lethal to $A$. aegypti did not affect the activity of cholinesterase and malate dehydrogenase, indicating the safety of these products.
\end{abstract}

Keywords: Cytotoxicity. Botanical insecticide. Dengue fever.

\section{INTRODUCTION}

Vector surveillance programs for dengue fever are one strategy to reduce its incidence in Brazil. Chemical insecticides are the most common strategy to reduce mosquito populations, although other options are available. Given the low effectiveness and high costs of these programs, there is a need to review control strategies as the figures clearly show that dengue fever is becoming endemic in Brazil ${ }^{(1)}$. The course of infection may be influenced by migration and urbanization, making disease monitoring and surveillance challenging ${ }^{(2)}$. This scenario is compounded by the continuous use of chemical insecticides, which has caused the target insects to develop resistance to various compounds, leading to the need for development of other forms of control using new products that are less harmful to humans and to the environment ${ }^{(3)}$.

Although resistance to insecticides can be seen as a process of rapid evolution within a population in response to selective pressure, it is pre-adaptive and is the result of random mutations

Corresponding author: Dra. Antonia Railda Roel.

e-mail: arroel@ucdb.br

Received 27 April 2016

Accepted 14 October 2016 whose mechanisms are related to the penetration rate of the insecticide into the vector's cuticle, its increased metabolic detoxification, and decreased sensitivity of the target site ${ }^{(4)}$.

Among the various related mechanisms, plant-based compounds are the main sources of new molecules with the potential for interacting with biological systems, acting at different stages of development and presenting different mechanisms of action ${ }^{(5)}$.

Plant-based products whose molecular complexity exerts lower selective pressure, leading to decreased resistance. Thus, the use of substances or formulations with differentiated activity are gaining ground in vector control when compared with conventional chemical insecticides, given the latter's toxicity and ability to cause changes in the target organism, their environmental impact, and their effect on human metabolism and the central nervous system ${ }^{(6)}$.

Botanical insecticides elicit less resistance and also accumulate more slowly in the environment owing to their low potency and dosages. However, for their effective use among the general population, they must meet all safety and efficacy requirements established by Brazilian regulatory agencies. The establishment of clinical toxicity protocols serves to evaluate the safety and monitoring methods used for chemical control. 
This study involved an in vitro evaluation of the effect of botanical insecticides formulated from cashew nutshell liquid $[\mathrm{A}]$ and ricinoleic acid $[\mathrm{B}]$ on the activity of the liver enzymes serum cholinesterase (ChE) and malate dehydrogenase (MDH).

\section{METHODS}

The formulated products were diluted according to the lethal concentrations determined in larvicidal assays for Aedes aegypti Linn. (1792) (Diptera: Culicidae), using the determined $\mathrm{LC}_{90}$ dosages of $0.135 \mathrm{mg} / \mathrm{mL}$ for liquid cashew nuts and $0.202 \mathrm{mg} /$ $\mathrm{mL}$ for ricinoleic acid as references ${ }^{(7)}$. The effects of botanical insecticides on the activity of liver enzymes were assessed as the ability inhibit $\mathrm{ChE}$ and increase MDH levels. The nicotinamide adenine dinucleotide (NAD) dehydrogenase disappearance rate correlates to the increase in MDH levels. Calibration curves indicated the linearity of each reaction between zero and the maximum absorbance of the enzyme at different concentrations, measured at the absorbance specific to each reaction, which was $410 \mathrm{~nm}$ for $\mathrm{ChE}$ and $340 \mathrm{~nm}$ for $\mathrm{MDH}$ in the ultraviolet range.

\section{Serum cholinesterase activity}

The action of products $[\mathrm{A}]$ and $[\mathrm{B}]$ on $\mathrm{ChE}$ activity was assessed by spectrophotometry ${ }^{(8)}{ }^{(9)}$. Serum cholinesterase hydrolyzes propionylthiocholine to release thiocholine, which reacts with 5,5'-dithiobis-2-nitrobenzoic acid (DTNB) - a color reagent - to form a yellow compound that is absorbed at $410 \mathrm{~nm}$ [Thermo Scientific ultraviolet (UV)-Vis, AquaMate $\left.{ }^{\circledR}\right]$. The substrate (propionylthiocholine) was added at a concentration of $0.43 \mathrm{~mol} / \mathrm{L}$. The enzyme activity assay was performed in triplicate at controlled temperature $\left(37^{\circ} \mathrm{C}\right)$ using distilled water $(4 \mathrm{~mL}), \mathrm{DTNB}(3 \mathrm{~mL})$, and $7.0 \mathrm{IU} / \mathrm{mL}(20 \mu \mathrm{l})$ of ChE. Product [A] was used at concentrations of $0.2,0.8$, and $1.5 \mathrm{~g} / \mathrm{L}$ and product [B] was used at concentrations of $0.035,0.123$, and $0.430 \mathrm{~g} / \mathrm{L}$, corresponding to $\mathrm{LC}_{10}, \mathrm{LC}_{50}$, and $\mathrm{LC}_{90}$. A positive control was prepared with substrate, DTNB, and enzyme, and the negative control was water and DTNB. Enzyme activity was inhibited using a solution of $0.5 \%$ quinidine sulfate $(3 \mathrm{~mL}), 30 \mathrm{sec}$ after additional of the enzyme.

Calibration curves were constructed using $\mathrm{ChE}$ at concentrations of $1.875,3.75,7.0,10.5,14.0$, and $17.5 \mathrm{IU} / \mathrm{mL}$. The straight line equation was $\mathrm{y}=0.861 \mathrm{x}+0.543, \mathrm{r}^{2}=0.9703$ (Figure 1).

\section{Transaminase activity}

Nicotinamide adenine dinucleotide (NAD) dehydrogenase is an intermediate of most biochemical reactions, but it cannot be directly quantified. NAD dehydrogenase was therefore quantified in triplicate by UV-spectrophotometry at $340 \mathrm{~nm}$ (Thermo Scientific UV-Vis, AquaMate $\AA$ ) following a coupling reaction with $\mathrm{MDH}$ at $37^{\circ} \mathrm{C}^{(10)}$.

For these assays, $1.5 \mathrm{~mL}$ of enzyme reagent (containing $\mathrm{MDH}$ ) and $0.5 \mathrm{~mL}$ of a solution containing NAD were heated to $37^{\circ} \mathrm{C}$. After $3 \mathrm{~min}, 200 \mu \mathrm{L}$ of products $[\mathrm{A}]$ and [B] at a concentration of $1 \mathrm{~g} / \mathrm{L}$ was added, while water was added to the positive control. The reaction was stopped after $1 \mathrm{~min}$ by adding $1 \mathrm{~mL}$ of $1 \mathrm{~mol} / \mathrm{L}$ sodium oxalate solution. Calibration

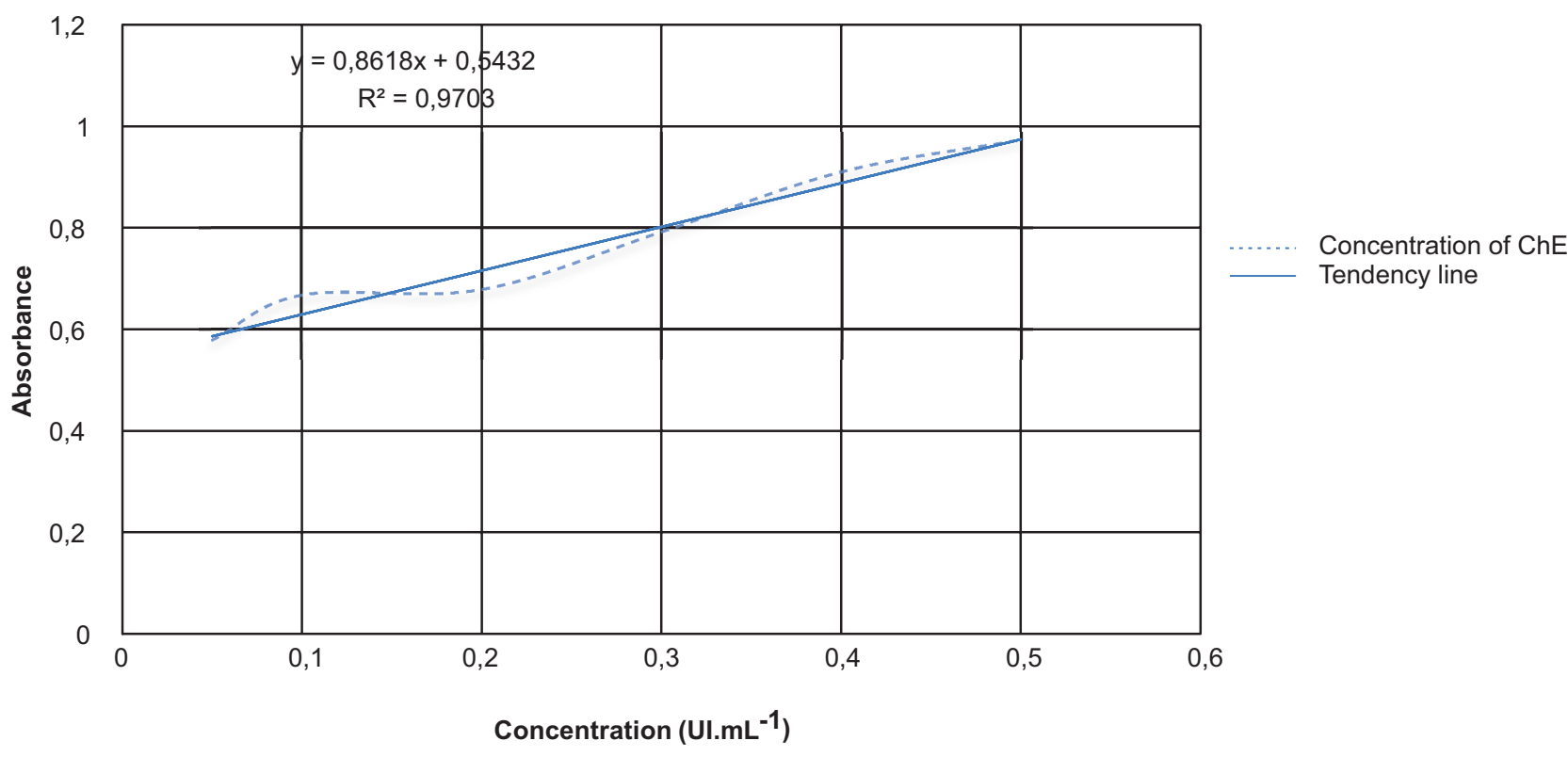

$\mathrm{Y}=\mathrm{ax}+\mathrm{b}$, reduced equation of the line

$\mathrm{R} 2=$ Determination coefficient

$\mathrm{UI} / \mathrm{mL}=$ international unit per $\mathrm{mL}$

FIGURE 1. Graphical representation of the relationship between absorbance at 410nm and concentration of serum cholinesterase dilutions of a standard solution of $7 \mathrm{IU} / \mathrm{mL}$. ChE: serum cholinesterase. 


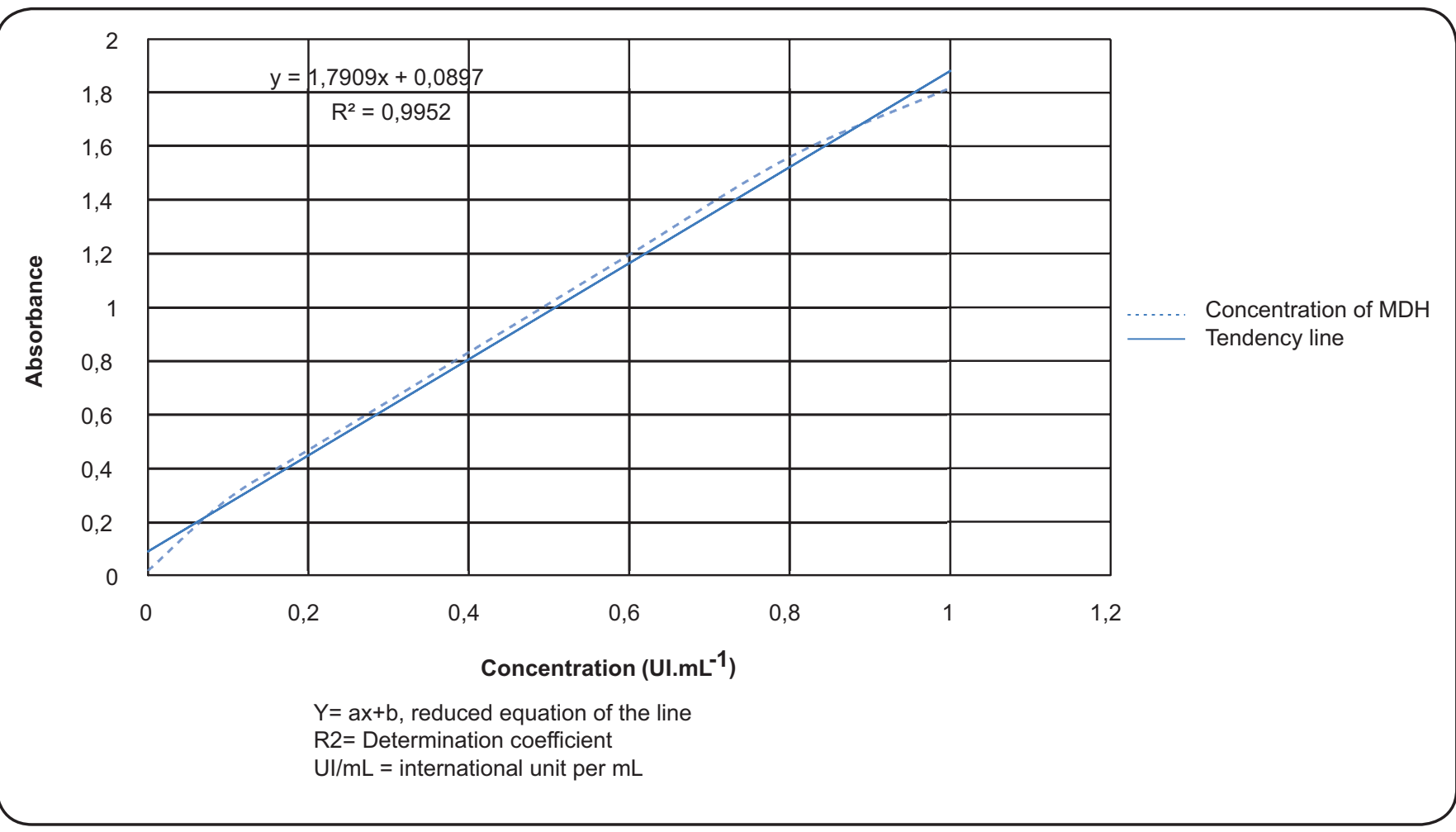

FIGURE 2. Graphical representation of the relationship between absorbance at 340nm and concentration of malate dehydrogenase dilutions of a standard solution of $0.48 \mathrm{IU} / \mathrm{mL}$. MDH: malate dehydrogenase.

curves were constructed using $\mathrm{MDH}$ at concentrations of 0.1 , $0.2,0.4,0.6,0.8$, and $1 \mathrm{IU} / \mathrm{mL}$. The straight line equation for MDH was $\mathrm{y}=1.790 \mathrm{x}+0.089 \mathrm{r}^{2}=0.9952$ (Figure 2).

\section{Sensitivity test}

The sensitivity of enzyme activity is directly related to the color generated by the enzymatic reaction with the substrate in the presence of the color reagent in aqueous medium.

The sensitivity test was designed to assess and monitor the analytical variability of $\mathrm{ChE}$ and $\mathrm{MDH}$ activity with standard solutions of $7 \mathrm{IU} / \mathrm{mL}$ and $0.48 \mathrm{UI} / \mathrm{mL}$, respectively.

\section{Determination of enzyme inhibition and statistical analysis}

Data on mean enzyme inhibition were analyzed using oneway analysis of variance (ANOVA) and Tukey's post-hoc test, at a significance level of 5\%, using the Statistical Assistance (ASSISTAT) version 7.7 beta software program (ASSISTAT 2015) $)^{(11)}$.

\section{RESULTS}

Sensitivity testing to ascertain the inhibition and stability of $\mathrm{ChE}$ in vitro indicated that different concentrations of the formulations did not inhibit enzyme activity at the significance level of the control ( $p$-value $<0.01)$. None of the values below the most toxic level of insecticide affected enzyme activity, and lower initial values than control were observed at the lowest concentration established on the linearity curve (Table 1).
Formulations $[\mathrm{A}]$ and $[\mathrm{B}]$ did not reduce the enzyme activity of ChE, which fell within the normal levels of 5-12IU/mL, with a mean value of $7.08 \mathrm{IU} / \mathrm{mL}$.

For the catalytic concentration pertaining to the oxidation of $\mathrm{MDH}$, it was found that the [A] and [B] formulations did not modify the predicted values for enzyme activity. A comparison of the positive control and tested sample values indicated that the average absorbance did not vary and that the values remained within the linear range, as shown in Table 2. ChE activity or NAD dehydrogenase were not affected by the insecticide formulations.

\section{DISCUSSION}

New products or formulations under study often pose serious threats to the ecosystem, not only because they suppress some metabolic mechanism of the target insect but also because of their cellular similarity to other organisms in the environment.

The dangers of and problems caused by the use of insecticides have long been known, as has the establishment of a model to explore the impact of these compounds on humans and the environment ${ }^{(12)}$.

Earlier study have revealed high esterase activity associated with the survival of the L4 larvae of $A$. aegypti, even when exposed to isolated chemicals ${ }^{(13)}$. This finding was observed in larvicidal studies in western Venezuela ${ }^{(14)}$, where the high efficiency of the chemical insecticide Temefos was found to be inversely proportional to the expression of the enzymatic activity of transaminases and acetylcholinesterase. 
TABLE 1

Determination of the inhibitory capacity of formulations [A] and [B] based on the analytical method for in vitro evaluation of serum cholinesterase at 410nm.

\begin{tabular}{lccc}
\hline Variables & Positive control for ChE & Formulation [A] & Formulation [B] \\
\hline $\mathrm{ChE}(\mathrm{IU} / \mathrm{mL}, \pm \mathrm{SD})$ & $8.36^{\mathrm{a}}(0.02)$ & $6.26^{\mathrm{b}}(0.04)$ & \\
Overall mean $\left(\mathrm{IU} / \mathrm{mL}^{-1}\right)$ & 7.08 & \\
Coefficient of variation $(\%)$ & 3.86 & & \\
\hline
\end{tabular}

ChE: serum cholinesterase; SD: standard deviation. ${ }^{\mathbf{a}, \mathbf{b}}$ Means sharing the same superscript letter are not significantly different from each other (Tukey's test at $5 \%$ significance). $\mathrm{UI} / \mathrm{mL}=$ international unit per $\mathrm{mL}$.

TABLE 2

Determination of the inhibitory capacity of formulations $[\mathrm{A}]$ and $[\mathrm{B}]$ based on of the analytical method for in vitro evaluation of malate dehydrogenase at $340 \mathrm{~nm}$.

\begin{tabular}{lccc}
\hline Variables & Positive control for ChE & Formulation $[\mathbf{A}]$ & Formulation $[\mathbf{B}]$ \\
\hline $\mathrm{MDH}(\mathrm{IU} / \mathrm{mL}, \pm \mathrm{SD})$ & $0.45^{\mathrm{a}}(0.11)$ & $0.43^{\mathrm{a}}(0.069)$ & \\
Overall mean $(\mathrm{IU} / \mathrm{mL})$ & 0.45 & \\
Coefficient of variation $(\%)$ & 18.99 & & \\
\hline
\end{tabular}

${ }^{2}$ Means sharing the same superscript letter are not significantly different from each other (Tukey's test at $5 \%$ significance). UI/mL $=$ international unit per mL.

Alterations in transaminase were also observed in the blister beetle, Mylabris pustulata (Thunberg, 1821), following exposure to sublethal doses of carbaryl, which inhibited enzyme levels after both short and long periods of treatment ${ }^{(15)}$.

The level of toxicity of insecticides to humans or the environment will depend on the toxicity of the substance or compound, its exposure time or accumulation, and the quantity employed. However, it is difficult to establish a diagnosis in the case of exposure to multiple components with differentiated mechanisms of action ${ }^{(16)}$.

It is common for insect species to use different resistance mechanisms to adapt to the pressure exerted by continuous use of an insecticide or to single molecules, and one mechanism of resistance that insects develop is the modification of the target protein of the insecticide, although the use of selective insecticides is a major factor in insect control ${ }^{(17)}$.

Cholinesterases are enzymes that promote the hydrolysis of acetylcholine, which acts as a neurotransmitter responsible for the transmission of nerve impulses. In the human body, true cholinesterases are classified as those present in red blood cells, the lungs, spleen, neurons, and in the brain, while pseudocholinesterases are those present in the liver plasma, pancreas, and intestine. In humans, the inhibition of acetylcholine hydrolysis caused by the presence of anticholinesterase substances leads to disorders of muscarinic (in smooth muscle, cardiac fibers, and exocrine glands) and nicotinic activity (in skeletal muscles and autonomic ganglia) ${ }^{(18)(19)}$. When poisoning by anticholinesterase agents occurs with inhibition exceeding $50 \%$ of the activity of the pool of cholinesterase, it is commonly accompanied by a severe acute cholinergic crisis, although stimulation of the parasympathetic nervous system with nicotinic receptor response is observed ${ }^{(20)}$.
The insensitivity of $\mathrm{ChE}$ to the action of insecticides is a frequent mechanism of resistance in insects ${ }^{(21)}$; hence, a botanical insecticide that does not reduce or block sensitivity is of particular value because it may also reduce the likelihood of health risks to humans.

Enzymatic and immunohistochemical evidence indicates a high degree of similarity to homologues that participate in mitochondrial electron transport involved in nicotinamide adenine dinucleotide (NADH) proton translocation between insects, fungi, and mammals, related to energy metabolism. The energy obtained from the oxidation of organic molecules in the form of reduced cofactors, such as NADH, is used to trigger the phosphorylation of adenosine diphosphate, which is energetically unfavorable, supplying adenosine triphosphate (ATP), which acts in coupled processes $^{(22)(23)}$. Thus, the presence of an inhibitor of the electron transport chain will adversely affect the production of ATP.

Increased hepatobiliary enzyme levels are one of the most sensitive markers used for the detection of drug-induced liver disease, also known as hepatotoxicity indicator serum liver enzymes. These enzymes are alanine transaminase (ALT), aspartate transaminase (AST), alkaline phosphatase, and gammaglutamyltransferase $(\gamma$-GT). These increases may indicate alterations ranging from adaptive biochemical and structural changes to morphological lesions, often with irreversible metabolic or cell damage. The risk is even greater when the substance is fat-soluble, enabling it to bind to plasma proteins until it reaches the liver, where it undergoes biotransformation into a water-soluble substance that is subsequently eliminated through biliary or renal excretion ${ }^{(24)}$. The results of MDH exposure to formulations [A] and [B], which are fat-dispersible substances, indicated that these products did not alter enzyme activity. Under the study conditions, the results also confirmed 
that these products are safe for humans in the event of exposure, although they are highly toxic to the target insect.

The identification and quantification of certain changes in organic systems, based on biochemical or physiological cell signaling, can be used for the biological monitoring of populations exposed not only to environmental but also industrial agents ${ }^{(22)}$. The assessment of enzymatic activity as a bioindicator serves not only to monitor the degree of exposure but also enables clinical or toxicological diagnosis associated with an effect or dysfunction of the biological system under evaluation ${ }^{(25)}$, as shown in previous studies involving rural workers exposed to organophosphates and carbamates ${ }^{(26)}$.

In summary, our findings show that in vitro testing of the formulated products at concentrations lethal to $A$. aegypti did not affect the enzymatic activity of $\mathrm{ChE}$ and $\mathrm{MDH}$, indicating the safety of these products. Furthermore, the in vitro enzymatic assays described here represent potential preliminary safety indicators for insecticide products as biochemical parameters are recognized as indicators of in vivo toxicity during assessment of the effects of exposure to these agents.

\section{Acknowledgments}

The authors gratefully acknowledge the support of Dom Bosco Catholic University (UCDB), the Federal University of Mato Grosso do Sul (UFMS), the Pantanal Research Center (CPP), the National Institute of Wetland Sciences and Technology (INAU) (through the Program National Institutes of Science and Technology of Brazil's National Council for Scientific and Technological Development, an agency of the Ministry of Science, Technology and Innovation $[\mathrm{CNPq} / \mathrm{MCTI}]$ ), and the Mato Grosso do Sul Foundation for the Support and Development of Education, Science and Technology (FUNDECT).

\section{Conflict of Interest}

The authors declare that there is no conflicts of interest.

\section{Financial Support}

Funding was provided by Dom Bosco Catholic University (UCDB), the National Institute of Wetland Sciences and Technology (INAU), and the Mato Grosso do Sul Foundation for the Support and Development of Education, Science and Technology (FUNDECT).

\section{REFERENCES}

1. Ferreira BJ, Souza MFM, Soares Filho AM, Carvalho AA. Evolução histórica dos programas de prevenção e controle da dengue no Brasil. Cien Saude Coletiva 2009; 14:961-972.

2. Magalhães SSA, Machado CJ. Conceitos epidemiológicos e as pandemias recentes: novos desafios. Cad Saude Colet 2014; 22:109-110.

3. Correa JCR, Salgado HRN. Atividade inseticida das plantas e aplicações: revisão. Rev Bras Plantas Med 2011; 13:500-506.

4. Braga IA, Valle D. Aedes aegypti: inseticidas, mecanismos de ação e resistência. Epidemiol Serv Saude 2007; 16:279-293.

5. Torres SM, Cruz NLN, Rolim VPM, Cavalcanti MIA, Alves LC, Silva Júnior VA. Cumulative mortality of Aedes aegypti larvae treated with compounds. Rev Saude Publica 2014; 48:445-450.

6. Aguiar-Menezes EL. Inseticidas Botânicos: seus princípios ativos, modo de ação e uso agrícola. Documento 205. Seropédica: Embrapa Agrobiologia. 2005. p.1-58.
7. Porto KRA, Roel AR, Machado AA, Cardoso CAL, Severino E, Oliveira JM. Atividade inseticida do líquido da castanha de caju sobre larvas de Aedes aegypti (Linnaeus, 1762) (Diptera: Culicidae). R Bras Bioci 2013; 11:419-422.

8. Ellin RI. Cholinesterase Determination (cont.). Clin Chem 1972; 18:487. PMID: 5019125.

9. Santos AC, Mostardeiro CP. Padronização de metodologia analítica para avaliação da colinesterase plasmática. Revista Contexto Saude 2008; 8:23-30.

10. Paiva de Oliveira MV. Aplicações de estudos bioquímicos quantitativos em ciências biológicas e da saúde. Renefara 2012; 2:99-127. Disponível em: http://www.fara.edu.br/sipe/index.php/ renefara/article/view/54

11. Assistência Estatística (ASSISTAT). Versão beta 7.7. Universidade Federal de Campina Grande. Campina Grande: 2015. Acesso: 06/01/2015. Disponível em: http://www.assistat.com.

12. Richardson JR, Shalat SL, Buckley B, Winnik B, O'Suilleabhain P, Diaz-Arrastia R et al. Elevated serum pesticide levels and risk of Parkinson disease. Arch Neurol 2009; 66:870-875.

13. Pereira BB. Efeitos do butóxido de piperonila na toxicidade do organofosforadoTemefós e o envolvimento de esterases na resistência de Aedes aegypti (Díptera: culicidae) ao Temefós. Dissertação de Mestrado. Uberlândia: Universidade Federal de Uberlândia; 2008. 36p.

14. Alvarez LC, Ponce G, Oviedo M, Lopez B, Flores AE. Susceptibility status of Aedes aegypti (L.) (Diptera: Culicidae) to temephos in Venezuela. Pest Manag Sci 2014; 70:1262-1266.

15. Bharathi D. Effects of carbaryl on the aminotransferases in the mid gut of blister beetle, Mylabris pustulata (Thunb). Toxicol Environ Chem 2008; 90:1125-1128.

16. Langer KCL, Guerino AC, Villas Boas GR. Análise das enzimas hepáticas em indivíduos que se submetem à exposição ocupacional a agrotóxicos de uso agrícola. Rev Pleiade 2012; 11:112-128.

17. dos Santos VMR, Donnici CL, DaCosta JBN, Caixeiro JMR. Compostos organofosforados pentavalentes: histórico, métodos sintéticos de preparação e aplicações como inseticidas e agentes antitumorais. Quim Nova 2007; 30:159-170.

18. Vasconcelos LFR, Leite AC, Nascimento OJM. Organophosphateinduced delayed neuropathy: case report. Arq Neuro-Psiquiatr 2002; 60:1003-1007.

19. Faria NMX, Fassa AG, Facchini LA. Intoxicação por agrotóxicos no Brasil: os sistemas oficiais de informação e desafios para realização de estudos epidemiológicos. Cien Saude Coletiva 2007; 12:25-38.

20. Barth VG, Biazon ACB. Complicações decorrentes da intoxicação por organofosforados. SaBios-Rev Saude Biol 2010; 5:27-33.

21. Guirado MM, Bicudo HEMC. Alguns aspectos do controle populacional e da resistência a inseticidas em Aedes aegypti (Diptera, Culicidae). BEPA. Bol Epidemiol Paulista (Online) 2009; 6:5-14.

22. Lümmen P. Complex I inhibitors as insecticides and acaricides. Biochim Biophys Acta 1998; 1364:287-296.

23. Cardol P. Mitochondrial NADH: ubiquinone oxidoreductase (complex I) in eukaryotes: a highly conserved subunit composition highlighted by mining of protein databases. Biochim Biophys Acta 2011; 1807:1390-1397.

24. de Almeida CG, Martins LHB. Enzimas hepáticas e acetilcolinesterase como biomarcadores de efeito dos agrotóxicos utilizados na cultura do Allium sativum. Rev Biocienc 2008; 14:117-126.

25. Vasconcelos THC, Modesto-Filho J, Diniz MFFM, Santos HB, Aguiar FB, Moreira PVL. Estudo toxicológico pré-clínico agudo com o extrato hidroalcoólico das folhas de Cissus sicyoides L. (Vitaceae). Rev Bras Farmacogn 2007; 17:583-591.

26. Silva JM, Novato-Silva E, Faria HP, Pinheiro TMM. Agrotóxico e trabalho: uma combinação perigosa para a saúde do trabalhador rural. Cienc Saude Coletiva 2005; 10:891-903. 